Pobrane z czasopisma Annales H - Oeconomia http://oeconomia.annales.umcs.pl Data: 26/04/2023 11:09:34

DOI:10.17951/h.2017.51.5.87

\begin{tabular}{lcr}
\hline & A N N A L E S \\
UNIVERSITATIS & MARIA A C URIE-S KŁ ODOW K A \\
LUBLIN - POLONIA & \\
VOL. LI, 5 & SECTIO H \\
\hline Uniwersytet Kardynała Stefana Wyszyńskiego w Warszawie. Wydział Nauk Historycznych i Społecznych
\end{tabular}

\title{
DARIUSZ FILIP
}

d.filip@uksw.edu.pl

\section{Czynniki organizacyjne funduszy wpływajace na poziom ryzyka inwestycyjnego}

The Influence of Organizational Fund Characteristics on Risk Level

Słowa kluczowe: fundusze inwestycyjne; ryzyko; wyniki; czynniki organizacyjne

Keywords: mutual funds; risk; performance; fund characteristics

Kod JEL: G11; G23; G29

\section{Wstęp}

Ryzyko inwestycji w fundusze inwestycyjne może być definiowane na kilka sposobów. W kontekście przewidywalności wyników ryzyko określane jest jako stopień zmiany wartości jednostek uczestnictwa. W tym przypadku miarą ryzyka może być wariancja wyników lub odchylenie standardowe. Ryzyko może być również opisywane przez stopień oddziaływania zmian wzorca odniesienia na zmiany ceny jednostek uczestnictwa. Podobnie można określać ryzyko funduszu przez odzwierciedlenie wzorca, jakim jest benchmark w osiąganych wynikach. W takim przypadku ocenia się umiejętność zarządzających w naśladowaniu benchmarku lub też uniezależnienia się od jego wpływu np. w okresach gorszej koniunktury. Wyżej wymieniona wrażliwość zmian oraz dopasowanie wyników do wzorca określać będzie stosowany w funduszu styl inwestycyjny.

Celem niniejszej pracy jest zbadanie zależności poziomu ryzyka opisującego inwestycje w fundusze od wybranych cech organizacyjnych charakteryzujących 
analizowane podmioty. W badaniu zostały wykorzystane cztery miary ryzyka, a także takie czynniki organizacyjne, jak wielkość i wiek funduszu oraz współczynnik napływu aktywów do funduszu.

Struktura niniejszego opracowania pozwala na wyodrębnienie kilku jego zasadniczych części. W pierwszej zostanie przeprowadzony krótki przegląd literatury przedmiotu umożliwiający odniesienie się do najistotniejszych rezultatów w ramach omawianego zagadnienia. W części drugiej zostaną przedstawione: zakres danych, rozwiązania metodologiczne oraz wykorzystane miary ryzyka. Część czwarta to prezentacja otrzymanych rezultatów badawczych wraz z ich interpretacją. Zamykającą częścią jest podsumowanie głównych ustaleń poczynionych w niniejszej pracy.

\section{Przegląd prac poświęconych analizie ryzyka w omawianych instytucjach finansowych}

Dorobek literatury poświęcony funduszom inwestycyjnym jest niezwykle obszerny. Praktycznie od samego początku prowadzonych analiz dotyczących instytucji pośrednictwa finansowego razem $\mathrm{z}$ badaniem wyników funduszy odnoszono się do analizy ryzyka inwestycyjnego. Badania obrazujące determinanty ryzyka nie są tak popularne, jak tematyka efektywności wyników. Niemniej należy wymienić opracowania takich autorów, jak Lintner [1965] czy choćby Blume [1971], które stanowią wkład m.in. w rozwój narzędzi pomiaru ryzyka w inwestycjach.

Wśród prac analizujących stopień ryzyka ponoszonego w funduszach inwestycyjnych można wskazać np. opracowanie Golca [1996]. Próbował on ustalić, czy atrybuty organizacyjne, ale i cechy menedżerskie, mogą tłumaczyć m.in. podejmowane przez fundusze ryzyko inwestycyjne. Próba badawcza składała się z 530 z funduszy akcji i dotyczyła okresu 1988-1990. Jako wskaźników ryzyka użyto miar reprezentujących ryzyko systematyczne i niesystematyczne. Otrzymane rezultaty pokazują, że zarówno wiek, jak i wielkość funduszu negatywnie wpływają na poziom odchylenia standardowego.

W innym badaniu Bliss, Potter i Schwarz [2008] starali się odpowiedzieć na pytanie, czy wyniki osiągane przez fundusze, ale również stopień ich zmienności, różnią się w zależności od tego, czy są one zarządzane przez pojedynczych menedżerów czy może przez zespoły zarządzających. Na próbce ponad 2500 funduszy akcji i mieszanych, funkcjonujących w latach 1993-2003, ustalili oni, że fundusze zarządzane przez zespoły wykazują się portfelami inwestycyjnymi o istotnie mniejszym ryzyku.

W jednej z nowszych prac poświęconych rynkom wschodzącym Vijayakumar, Sivanmalaiappan i Chandrasekhara Rao [2012] badali związek między wynikami a cechami funduszy. Analizie poddano 14 funduszy lokujących aktywa w akcje lub obligacje w Indiach w okresie 2004-2008. Wśród uwzględnionych determinant były: stopień ryzyka, wielkość funduszu, wskaźnik obrotu walorów w portfelu, 
wskaźnik wzrostu i wskaźnik kosztów. Dzięki panelowej analizie danych otrzymano rezultaty świadczące o tym, że osiągane wyniki są pozytywnie związane z ryzykiem, wielkością funduszu oraz wskaźnikiem kosztów, natomiast ujemnie są związane ze wskaźnikiem obrotu walorów w portfelu.

W polskich opracowaniach zagadnieniem poziomu ryzyka w funduszach zajmowano się głównie w kontekście doboru miar wyników ważonych ryzykiem. Jedną z podstawowych prac, w której analizowano rynek funduszy inwestycyjnych pod kątem jego efektywności, było badanie Czekaja, Wosia i Żarnowskiego [2001]. Wspomniani autorzy na próbie 29 funduszy akcji wycenianych w latach 1999-2000 ocenili umiejętności selekcyjne zarządzających oraz umiejętności wyczucia rynku, wykorzystując wskaźniki pomiaru stóp zwrotu ważonych ryzykiem.

Kolejne badania, np. Witkowskiej [2009], polegały na ocenie efektów gospodarowania całości rynku funduszy inwestycyjnych. We wspomnianej pracy autorka na podstawie 20 funduszy akcji krajowych i zagranicznych, funkcjonujących w okresie 2005-2007, odniosła się do ich efektywności. Wykorzystując popularne miary wyników oraz sposoby pomiaru ryzyka, określiła ona najbardziej atrakcyjne z perspektywy klienta podmioty, które osiągały stopy zwrotu wyższe niż rynek, przy niższym od rynku ryzyku.

Z kolei Filip [2016] na przykładzie stosunkowo dużej próby badawczej (221 podmiotów), na którą składały się krajowe fundusze akcji, mieszane oraz obligacji, odnoszącej się do okresu 2000-2015, próbował oceniać efektywność funduszy przez zestawienie osiąganych stóp zwrotu z poziomem ryzyka inwestycyjnego podejmowanego przez te podmioty. W wyniku przeprowadzonej analizy zaobserwowano, że przy zwiększeniu zaangażowania inwestycji w papiery właścicielskie zwiększał się poziom ryzyka rynkowego i specyficznego.

\section{Procedura badawcza}

\subsection{Sposoby pomiaru ryzyka}

Jak wspomniano wcześniej, pomiar ryzyka jest jednym z elementów oceny zarządzania aktywami. Metody jego mierzenia można sklasyfikować w kilku kategoriach. W ramach pierwszej z nich - miar zmienności - wymienia się odchylenie standardowe. Same miary zmienności odzwierciedlają zmiany stóp zwrotu, poza tym na ich podstawie można ustalać rozproszenie rozkładu. Wykorzystane narzędzie jest definiowane jako miara ryzyka niesystematycznego i wykorzystuje się do jego pomiaru podstawowy wzór:

$$
S D_{i, t}=\frac{\sqrt{\sum_{i=1}^{n}\left(r_{i, t}-\bar{r}_{i}\right)^{2}}}{n-1}
$$


gdzie:

$S D_{i, t}$ - odchylenie standardowe funduszu $i$

$r_{i, t}$ - stopa zwrotu funduszu $i$ w okresie $t$

$\bar{r}_{i}-$ średnia stopa zwrotu funduszu $i$

$n$ - liczba uwzględnionych okresów

Wskaźnik ten, pozwalający ocenić historyczną zmienność inwestycji, pokazuje odchylenia stóp zwrotu funduszu od ich średniej w danym okresie.

Druga z miar ryzyka należy do kategorii miar zagrożenia. Miary zagrożenia odnoszą się do pomiaru możliwych niekorzystnych odchyleń od oczekiwanych stóp zwrotu. W tym celu wykorzystuje się semiodchylenie, które jest miernikiem jedynie ujemnych odchyleń [zob. Jajuga, Jajuga, 2006]:

$$
\operatorname{SemiSD}_{i, t}=\frac{\sqrt{\sum_{i=1}^{n}\left(r_{i, t}-\bar{r}_{i}\right)^{2}-}}{n-1}
$$

gdzie:

$S e m i S D_{i, t}$ - odpowiednik odchylenia standardowego stopy zwrotu uwzględniający jedynie ujemne odchylenia (symbol ,,_') od oczekiwanej stopy zwrotu funduszu $i$

Trzeci sposób pomiaru ryzyka odnosi się do miar wrażliwości, które odzwierciedlają wpływ pewnych zmiennych (zwanych czynnikami ryzyka) na stopy zwrotu. Wykorzystanym w tym kryterium sposobem pomiaru ryzyka jest współczynnik beta. Współczynnik ten, oznaczający tzw. ryzyko systematyczne, określany jest jako miara wskazująca wrażliwość zmiany ceny jednostki uczestnictwa w porównaniu ze zmianą benchmarku i liczona jest w oparciu o następujący wzór [Gandhi, Perumal, 2016]:

$$
\beta_{i, t}=\frac{\sum_{i=1}\left(r_{i, t}-\bar{r}_{i}\right)\left(r_{m, t}-\overline{r_{m}}\right.}{\sum_{i=1}^{n}\left(r_{m, t}-\overline{r_{m}}\right)^{2}}
$$

gdzie:

$\beta_{i, t}-$ współczynnik beta funduszu $i$

$\bar{r}_{m, t}-$ średnia stopa zwrotu benchmarku

Aby w sposób bardziej dokładny określić wrażliwość zmiany stopy zwrotu funduszu na zmiany stopy zwrotu wzorca odniesienia, równolegle do wyżej wskazanego współczynnika stosuje się wskaźnik determinacji $\mathrm{R}^{2}$, pokazujący stopień statystycznego dopasowania serii danych (np. stóp zwrotu) do wzorca, jakim jest indeks rynkowy. Za pomocą poniższego wzoru ustala się, jaki procent historycznych wartości funduszu może być tłumaczony porównawczym indeksem [zob. Amihud, Goyenko, 2013]: 


$$
R_{i, t}^{2}=\frac{\sum_{i=1}^{n}\left(\widehat{r}_{i}-\bar{r}_{i}\right)^{2}}{\sum_{i=1}^{n}\left(r_{i, t}-\bar{r}_{i}\right)^{2}}
$$

gdzie:

$R^{2}{ }_{i, t}$ - wskaźnik determinacji funduszu $i$

$\widehat{r}_{i}$ - teoretyczna wartość funduszu i estymowana za pomocą modelu rynku kapitałowego

Do pomiaru ryzyka współczynnikiem beta oraz wskaźnikiem determinacji zostały wykorzystane odpowiednio skonstruowane portfele wzorcowe starające się odzwierciedlać styl oraz politykę inwestycyjną funduszy mieszanych. Dla funduszy stabilnego wzrostu była to kompilacja indeksów WIG oraz IROS w stosunku 30:70, a dla funduszy zrównoważonych - 50:50. Fundusze aktywnej alokacji, charakteryzujące się dużą swobodą inwestycyjną, nie posiadają jednolitych benchmarków, jednak do celów badawczych wykorzystano wzorcowy portfel podobny do funduszy zrównoważonych (50:50).

\subsection{Wykorzystane narzędzia badawcze}

W celu ilościowego ujęcia związków pomiędzy wieloma zmiennymi niezależnymi a zmienną zależną wykorzystuje się funkcję regresji wielorakiej. Związek poziomu ryzyka oraz właściwości organizacyjnych funduszy może być ustalony na podstawie poniższej formuły:

$$
\operatorname{Risk}_{i, t}=f\left(\operatorname{SIZE}_{i, t} ; A G E_{i, t} ; F_{L O W}{ }_{i, t-1}\right)
$$

gdzie:

Risk $_{i}$ - zastosowany w danym modelu sposób pomiaru ryzyka inwestycyjnego funduszu $i$

SIZE - wielkość funduszu $i$ liczona jako logarytm naturalny z wartości aktywów będących w posiadaniu funduszu $i \mathrm{w}$ danym roku

$A G E$ - wiek funduszu $i$ liczony jako logarytm naturalny z liczby miesięcy od momentu pierwszej wyceny wartości jednostek uczestnictwa

$F L O W$ - napływ aktywów do funduszu $i$ w okresie $t-1$

Testowana hipoteza zerowa, w przypadku przeprowadzanej analizy regresji, mówi o tym, że poziom ryzyka inwestycyjnego nie zależy od poszczególnych cech organizacyjnych funduszy. Statystyczna istotność współczynnika stojącego przy regresorze będzie weryfikowana testem $t$. W przypadku, gdy obliczona wartość statystyki testowej jest większa co do modułu od wartości krytycznej odczytanej 
z tablic rozkładu t-Studenta dla danego poziomu istotności, da to podstawy do odrzucenia hipotezy zerowej na korzyść hipotezy alternatywnej, mówiącej o istnieniu zależności poziomu ryzyka od pewnych atrybutów funduszy. W celu sprawdzenia łącznej istotności parametrów posłużono się testem Walda.

Ze względu na opis zbiorowości funduszy w więcej niż jednym okresie uzasadnione wydaje się użycie podejść dla danych przekrojowo-czasowych. Estymacja parametrów będzie prowadzona za pomocą dwóch metod, tj. rozległej klasycznej metody najmniejszych kwadratów (OLS) oraz regresji stałych efektów (FER). Pierwsze z wyżej wymienionych podejść jest regresją względem wszystkich danych bez rozróżnienia pomiędzy komponentami. Druga metoda, dedykowana właśnie dla badań panelowych, uwzględnia charakter błędów standardowych.

\subsection{Opis danych empirycznych}

Próba badawcza składała się z 69 otwartych krajowych funduszy mieszanych dokonujących wyceny wartości jednostek uczestnictwa w okresie 2000-2015. W tab. 1 zaprezentowano liczebność funduszy inwestycyjnych w podziale na główne grupy funduszy o podobnej polityce inwestycyjnej i składach portfeli w poszczególnych latach horyzontu badania.

Tab. 1. Liczba funduszy inwestycyjnych uwzględnionych w badaniu

\begin{tabular}{|c|c|c|c|c|c|c|c|c|c|c|c|c|c|c|c|c|}
\hline Lata & \multirow{2}{*}{ 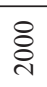 } & \multirow{2}{*}{ 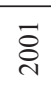 } & \multirow{2}{*}{ ชิ } & \multirow{2}{*}{ 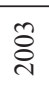 } & \multirow{2}{*}{ ঠ্ণ } & \multirow{2}{*}{$\stackrel{n}{\circledR}$} & \multirow{2}{*}{$\stackrel{\circ}{\circ}$} & \multirow{2}{*}{ હิ } & \multirow{2}{*}{$\stackrel{\infty}{\stackrel{ᄋ}{0}}$} & \multirow{2}{*}{ 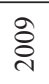 } & \multirow{2}{*}{$\stackrel{\circ}{\stackrel{0}{\circ}}$} & \multirow{2}{*}{$\bar{\Xi}$} & \multirow{2}{*}{$\stackrel{\sim}{\stackrel{\sim}{\circ}}$} & \multirow{2}{*}{$\frac{n}{2}$} & \multirow{2}{*}{$\frac{ \pm}{\circ}$} & \multirow{2}{*}{ in } \\
\hline Liczebność & & & & & & & & & & & & & & & & \\
\hline $\begin{array}{l}\text { Wszystkie fundusze } \\
\text { mieszane, w tym: }\end{array}$ & 13 & 16 & 21 & 24 & 29 & 33 & 35 & 40 & 42 & 44 & 47 & 51 & 55 & 61 & 69 & 69 \\
\hline $\begin{array}{l}\text { - fundusze } \\
\text { stabilnego wzrostu }\end{array}$ & 6 & 8 & 10 & 13 & 18 & 21 & 21 & 22 & 22 & 23 & 24 & 25 & 26 & 28 & 33 & 33 \\
\hline $\begin{array}{l}\text { - fundusze } \\
\text { zrównoważone }\end{array}$ & 7 & 8 & 10 & 10 & 10 & 11 & 12 & 13 & 13 & 13 & 14 & 15 & 15 & 15 & 16 & 16 \\
\hline $\begin{array}{l}\text { - fundusze } \\
\text { aktywnej alokacji }\end{array}$ & 0 & 0 & 0 & 0 & 0 & 0 & 1 & 4 & 6 & 7 & 8 & 10 & 12 & 16 & 18 & 18 \\
\hline
\end{tabular}

Źródło: opracowanie własne.

Zgromadzona baza danych dotyczyła wartości określających poziom ryzyka inwestycyjnego oraz organizacyjnych aspektów funkcjonowania. Wszystkie roczne współczynniki określające poziom ryzyka obliczane były na podstawie obserwacji miesięcznych. Z kolei czynniki organizacyjne, takie jak wielkość funduszu, wiek funduszu oraz wskaźnik napływu aktywów, określane były na koniec każdego roku. Źródłem wyżej wymienionych danych były informacje pochodzące z serwisu Analizy Online. 


\section{Rezultaty}

Prezentacja otrzymanych rezultatów będzie się składać z dwóch etapów. W pierwszym z nich zostaną zaprezentowane główne rezultaty dotyczące całej próby badawczej bez rozróżnienia stylów inwestycyjnych. Próba badawcza składała się z 69 podmiotów, co w łącznym okresie analizy dało 649 obserwacji. Tab. 2 przedstawia m.in. wartości parametrów związanych z czynnikami organizacyjnymi oszacowanymi dla czterech miar ryzyka.

Jak wynika z przeprowadzonej analizy, niezależnie od zastosowanego sposobu pomiaru ryzyka wraz ze zwiększaniem się wartości aktywów zarządzanych przez fundusze poziom zmienności, zagrożenia, wrażliwości oraz dopasowania do wzorca ulegał zwiększeniu w całej próbie badawczej. Oznacza to, że analizowane fundusze mieszane przy zwiększaniu bazy kapitałowej bardziej dywersyfikują swoje portfele, co doprowadza do zbliżenia się do benchmarku, decydując się jednocześnie na papiery wartościowe o większej zmienności dochodu. Czynnik określający wiek funduszu był w stanie istotnie oddziaływać na poziom ryzyka, ale głównie mierzonego współczynnikiem beta oraz wskaźnikiem determinacji. W związku z tym można przyjąć, że generalnie im starszy fundusz, tym bardziej jest w stanie dopasować swój portfel do wzorca odniesienia.

Druga część badania objęła dane uszczegóławiające, związane z wpływem analizowanych czynników na stopień ryzyka inwestycyjnego w poszczególnych homogenicznych grupach funduszy mieszanych, czyli z uwzględnieniem zbliżonych stylów inwestycyjnych. Próba badawcza została podzielona na trzy podgrupy, na które składały się fundusze stabilnego wzrostu (33 podmioty z liczbą obserwacji 333), fundusze zrównoważone (16 podmiotów z liczbą obserwacji 198) oraz fundusze aktywnej alokacji (18 podmiotów z liczbą obserwacji 100). Tab. 3 zawiera wyniki estymacji parametrów modeli opisujących trzy wspomniane podpróby.

Podobnie jak dla całej próby badawczej, wielkość aktywów będących w posiadaniu poszczególnych grup funduszy dodatnio oddziaływała na poziom ryzyka inwestycyjnego. Najsilniejszy wpływ tego wskaźnika na zmienność wyników przy użyciu dwóch metod badawczych obserwowany był w funduszach zrównoważonych oraz częściowo w aktywnej alokacji. Wydaje się to uzasadnione ze względu na stosowaną $\mathrm{w}$ tych grupach funduszy politykę oraz styl inwestycyjny. Z kolei w analizie wrażliwości na zmiany stóp zwrotu wzorca oraz dopasowania wyników do benchmarku najwyższe wartości parametrów stojących przy wielkości aktywów, potwierdzone jednocześnie w dwóch metodach badawczych, otrzymano dla funduszy stabilnego wzrostu. Oznacza to, że wraz ze zwiększaniem się bazy kapitałowej fundusze te lepiej wyrażają stopień wyjaśnienia zmienności stopy zwrotu przez poszczególne benchmarki.

Zmienność wyników, mierzona odchyleniem oraz semiodchyleniem standardowym, mogła być ujemnie wyjaśniana przez parametr określający wiek funduszu, lecz jedynie dla funduszy zrównoważonych. Zatem im starszy fundusz w ramach 
Pobrane z czasopisma Annales H - Oeconomia http://oeconomia.annales.umcs.pl

Data: 26/04/2023 11:09:34

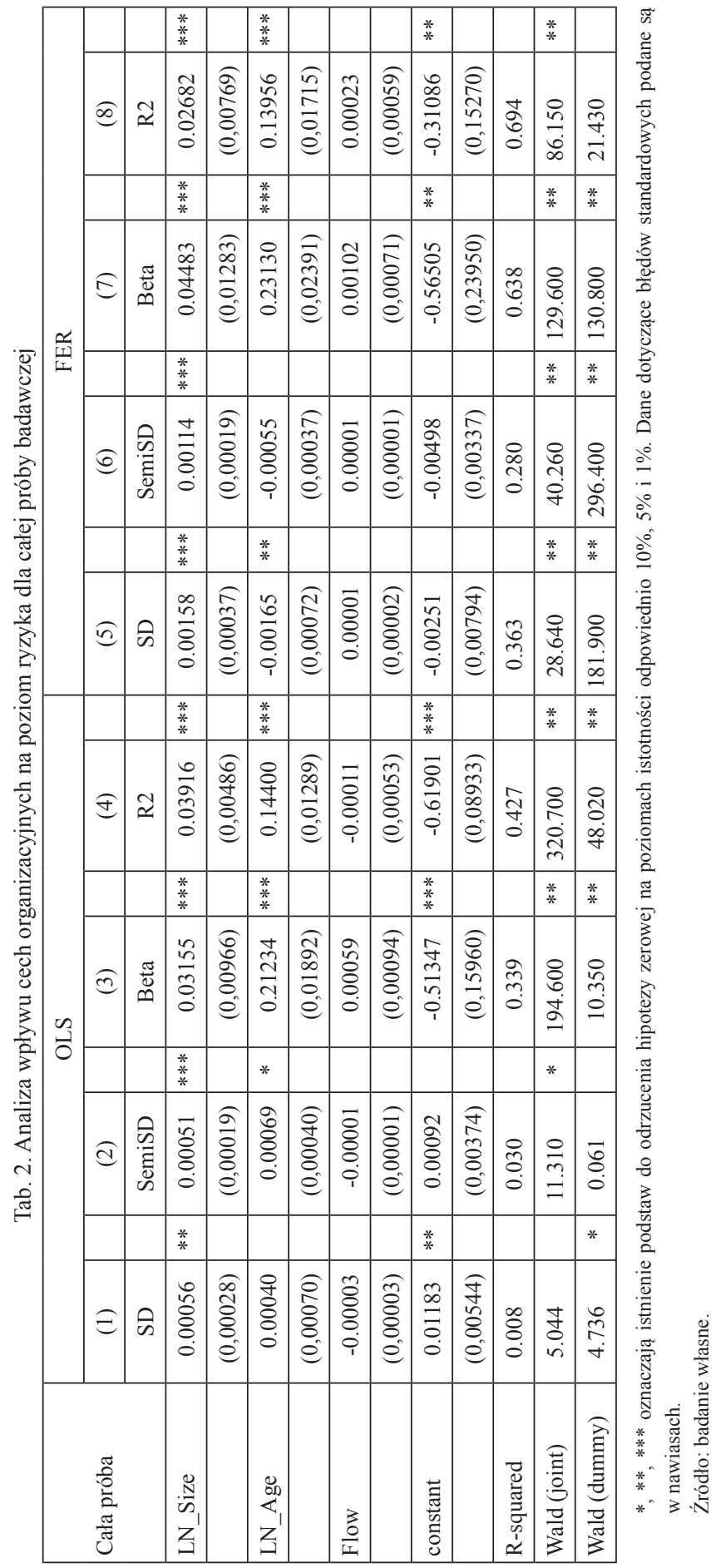


Pobrane z czasopisma Annales H - Oeconomia http://oeconomia.annales.umcs.pl

Data: 26/04/2023 11:09:34

CZYNNIKI ORGANIZACYJNE FUNDUSZY WPLYWAJĄCE NA POZIOM RYZYKA INWESTYCYJNEGO

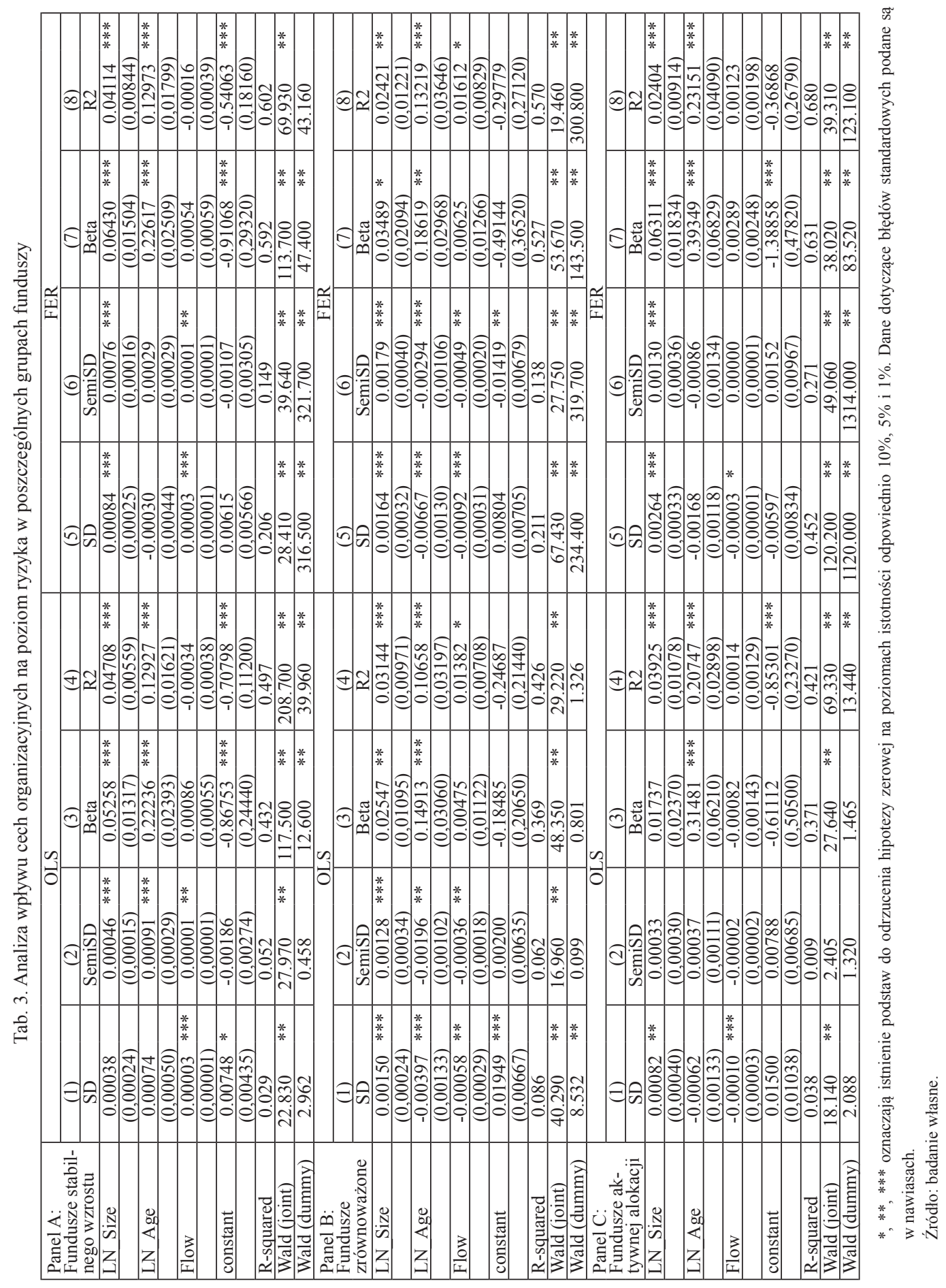


tej grupy, tym bardziej jego zarządzający dobierali do portfela mniej zmienne papiery wartościowe. Należy pamiętać, że poziom ryzyka jest pochodną przyjętej strategii inwestycyjnej stosowanej przez danego menedżera. W długich okresach funkcjonowania funduszy mogły zachodzić zmiany na stanowiskach zarządzających, jednak w niniejszym badaniu nie uwzględniono czynnika fluktuacji kadry. W każdej $\mathrm{z}$ trzech podprób wiek funduszu statystycznie istotnie oraz dodatnio wpływał na ryzyko mierzone współczynnikiem beta oraz wskaźnikiem determinacji. Jednak analiza dopasowania i wrażliwości na benchmark nie dostarczyła znaczących różnic w rezultatach dotyczących omawianych grup funduszy. Badanie znaczenia rocznego wskaźnika napływu aktywów nie przyniosło jednoznacznych rezultatów.

\section{Podsumowanie}

Celem niniejszej pracy było zbadanie zależności poziomu ryzyka opisującego inwestycje w fundusze od wybranych cech organizacyjnych charakteryzujących omawiane instytucje pośrednictwa finansowego. Badaniu został poddany stosunkowo duży segment otwartych funduszy inwestycyjnych lokujących aktywa zarówno w papiery właścicielskie, jak i dłużne papiery wartościowe. Różnorodność składów portfeli krajowych funduszy mieszanych skłonił autora do analizy ryzyka inwestycyjnego w całej próbie badawczej oraz w poszczególnych homogenicznych grupach charakteryzujących się określoną polityką inwestycyjną. Analizę przeprowadzono dla 69 podmiotów w okresie 2000-2015. Wspomnianymi grupami były fundusze stabilnego wzrostu, zrównoważone oraz aktywnej alokacji. Wśród miar ryzyka, będących zmiennymi objaśnianymi, uwzględniono odchylenie standardowe, semiodchylenie, współczynnik beta i wskaźnik determinacji. Zmiennymi objaśniającymi z kolei były wielkość i wiek funduszu oraz współczynnik napływu aktywów do funduszu. Aparat badawczy stanowiły dwie metody regresji dla danych przestrzenno-czasowych, tj. rozległa klasyczna metoda najmniejszych kwadratów oraz regresja stałych efektów.

W wyniku przeprowadzonej analizy ustalono, że w każdej z użytych metod badawczych wraz ze zwiększaniem się wartości aktywów zarządzanych przez fundusze poziom zmienności, zagrożenia, wrażliwości i dopasowania do wzorca ulegał zwiększeniu. Rezultat ten był obserwowany zarówno w całej próbie badawczej, jak i w poszczególnych grupach funduszy mieszanych. Szczególnie dla funduszy zrównoważonych zauważono, że przy zwiększaniu bazy kapitałowej mogą one bardziej dywersyfikować swoje portfele, co też skutkuje zbliżaniem się do wzorca odniesienia. $Z$ drugiej strony mogą one decydować się na inwestycje w papiery wartościowe o większej zmienności dochodu. Z kolei parametr określający wiek funduszu istotnie wpływał na poziom ryzyka mierzonego współczynnikiem beta oraz wskaźnikiem determinacji tak w całej próbie, jak i w poszczególnych grupach funduszy. Natomiast oddziaływanie wieku podmiotu na zmienność wyników, mierzoną odchyleniem oraz semiodchyleniem standardowym, okazało się ujemne, ale 
tylko dla funduszy zrównoważonych. Oznacza to, że wraz z wiekiem podmiotów we wspomnianej grupie ich zarządzający dobierali do portfela papiery wartościowe charakteryzujące się mniejszą zmiennością.

\section{Bibliografia}

Amihud Y., Goyenko R., Mutual Fund's R2 as Predictor of Performance, "Review of Financial Studies" 2013, Vol. 26(3), DOI: https://doi.org/10.1093/rfs/hhs182.

Bliss R.T., Potter M., Schwarz Ch., Performance Characteristics of Individual vs. Team Managed Mutual Funds, "Journal of Portfolio Management" 2008, Vol. 34(3),

DOI: https://doi.org/10.3905/jpm.2008.706248.

Blume M.E., On the Assessment of Risk, "The Journal of Finance" 1971, Vol. 26(1),

DOI: https://doi.org/10.1111/j.1540-6261.1971.tb00584.x.

Czekaj J., Woś M., Żarnowski J., Efektywność giełdowego rynku akcji w Polsce, PWN, Warszawa 2001.

Filip D., Pomiar wyników oraz ryzyka polskich funduszy inwestycyjnych, „Zarządzanie Finansami i Rachunkowość" 2016, nr 4(2).

Gandhi R.K., Perumal R., Performance of Selected Bank Mutual Funds Schemes Impact in Investors' Decision Making, "International Journal of Advanced Research" 2016, Vol. 5(3).

Golec J.H., The effects of mutual fund managers' characteristics on their portfolio performance, risk and fees, "Financial Services Review"1996, Vol. 5(2), DOI: https://doi.org/10.1016/S1057-0810(96)90006-2.

Jajuga K., Jajuga T., Inwestycje - instrumenty finansowe - ryzyko finansowe - inżynieria finansowa, PWN, Warszawa 2006.

Lintner J., The Valuation of Risk Assets and the Selection of Risky Investments in Stock Portfolios and Capital Budgets, "The Review of Economics and Statistics" 1965, Vol. 47(1),

DOI: https://doi.org/10.2307/1924119.

Vijayakumar N., Sivanmalaiappan M., Chandrasekhara Rao K., The Relationship Between Fund Performance and Fund Characteristics: Evidence from India, "The IUP Journal of Applied Finance" 2012, Vol. 18(2).

Witkowska D., Efektywność wybranych funduszy akcyjnych w latach 2005-2007, „Ekonomika i Organizacja Gospodarki Żywnościowej” 2009, nr 74.

\section{The Influence of Organizational Fund Characteristics on Risk Level}

The aim of the article was to examine the dependence of level of investment risk on selected organizational fund characteristics. The analysis was conducted for 69 domestic mixed funds, divided into stable growth funds, balanced funds and active allocation funds, operated in the 2000-2015 period. The study employed 4 popular measures of risk and organizational factors such as size, age and inflow rate. By means of two regression methods for time-series cross-section data there was revealed that an increase of assets under management positively influences the level of variability, volatility, sensitivity and accuracy of the benchmark. A fund age factor was able to significantly influence the risk level measured mainly by beta and determination coefficients. The mentioned variable negatively impacted on variability of returns only for balanced funds. 
Pobrane z czasopisma Annales $\mathrm{H}$ - Oeconomia http://oeconomia.annales.umcs.pl

Data: 26/04/2023 11:09:34

\section{Czynniki organizacyjne funduszy wpływające na poziom ryzyka inwestycyjnego}

Celem artykułu było zbadanie zależności poziomu ryzyka inwestycyjnego od wybranych cech organizacyjnych. Analizę przeprowadzono dla 69 krajowych funduszy mieszanych, z podziałem na fundusze stabilnego wzrostu, zrównoważone oraz aktywnej alokacji, działających w okresie 2000-2015. W badaniu uwzględniono cztery popularne miary ryzyka oraz czynniki organizacyjne, takie jak: wielkość i wiek funduszu oraz współczynnik napływu aktywów do funduszu. W wyniku użycia dwóch metod regresji dla danych przestrzenno-czasowych ustalono, że wraz ze zwiększaniem się wartości aktywów zarządzanych przez fundusze, poziom zmienności, zagrożenia, wrażliwości oraz dopasowania do wzorca ulegał zwiększeniu. Czynnik określający wiek funduszu był w stanie istotnie oddziaływać na poziom ryzyka, ale głównie mierzonego współczynnikiem beta oraz wskaźnikiem determinacji. Jedynie w funduszach zrównoważonych wiek podmiotu ujemnie wpływał na zmienność wyników. 